\title{
OPEN ACCESS \\ First isolation and genotyping of viruses from recent outbreaks of viral haemorrhagic septicaemia (VHS) in Slovenia
}

\author{
Ivan Toplak ${ }^{1, *}$, Peter Hostnik ${ }^{1}$, Danijela Rihtarič ${ }^{1}$, Niels Jørgen Olesen ${ }^{3}$, \\ Helle Frank Skall ${ }^{3}$, Vlasta Jenčič ${ }^{2}$ \\ ${ }^{1}$ Virology Unit, Institute of Microbiology and Parasitology, \\ and ${ }^{2}$ Institute for Health Care and Breeding of Wild Animals Fishes and Bees, Veterinary Faculty, University of Ljubljana, \\ Gerbičeva 60, 1115 Ljubljana, Slovenia \\ ${ }^{3}$ Fish Diseases Section, Technical University of Denmark, National Veterinary Institute, Hangøvej 2, 8200 Århus N, Denmark
}

\begin{abstract}
In November and December 2007, the virus causing viral haemorrhagic septicaemia (VHS) was detected in rainbow trout Oncorhynchus mykiss from 2 fish farms in Slovenia. During 2008 and 2009 the infection spread only among rainbow trout farms and 4 new outbreaks were confirmed. High mortality and clinical signs of VHS were observed among the diseased fish. VHSV was confirmed by virus isolation, immunoperoxidase test, reverse transcriptase polymerase chain reaction (RT-PCR) and phylogenetic analysis. Based on 1 complete (1524 nucleotides [nt]) and 9 partial (600 nt) glycoprotein gene nucleotide sequences, 9 VHSV isolates from the 6 VHS outbreaks were genetically closely related (99 to $100 \%$ identity), and were classified into the Subgroup I-a of Genotype I, most closely related to the German isolates Dstg21-07, Dstg36-06, and Dstg54-1-07 (99 to $100 \%$ identity). Phylogenetic analysis and epidemiological investigations confirmed that the VHS virus had been (re)introduced with imported live fish, and that subsequent outbreaks were linked to the initial infection. Our study shows that direct nucleotide sequencing of RT-PCR products, amplified from the tissue of VHSV-infected fish, represents a reliable tool for fast routine genotyping in diagnostic laboratories. This is the first report of a natural epidemic associated with VHSV infection in Slovenia since the eradication of the disease in 1977.
\end{abstract}

KEY WORDS: Viral haemoragic septicaemia virus $\cdot$ VHSV $\cdot$ Rainbow trout $\cdot$ Epidemiology $\cdot$ Slovenia Resale or republication not permitted without written consent of the publisher

\section{INTRODUCTION}

Viral haemorrhagic septicaemia virus (VHSV) is an enveloped negative-strand RNA virus belonging to the genus Novirhabdovirus of the Rhabdoviridae family. The VHSV genome consists of $\sim 11200$ nucleotides (nt) and contains 6 genes in the order 3'-N-P-M-G-Nv-L-5', encoding a non-structural protein $(\mathrm{Nv})$ and 5 structural proteins: nucleocapsid (N-), phospho- (P-), matrix (M-), glyco- (G-) and RNA polymerase (L-) protein, respectively (Schütze et al. 1999). The virus was isolated from at least 45 species of marine and fresh water fishes (OIE 2010) with many marine fish species appearing to be asymptomatically infected; suggesting viral haemorrhagic septicaemia (VHS) is endemic among marine fishes (Dixon, 1999, Smail, 1999, Einer-Jensen al. 2004). The first isolation of VHSV occurred in 1962 in Denmark (Jensen 1965). VHS is one of the most serious viral diseases of farmed rainbow trout Oncorhynchus mykiss in continental European countries where it causes extensive losses in salmon aquaculture (Wolf 1988, Smail 1999). Typical outbreaks involve fingerlings to 1 yr old rainbow trout, but the disease can also affect adult rainbow trout and causes mortality among several other salmon and non-salmon species (Wolf 1988, Skall et al. 2005, USGS 2008). Epidemic losses occur at temperatures of 3 to $12^{\circ} \mathrm{C}$, but deaths from VHS rarely occur at temperatures $>15^{\circ} \mathrm{C}$. Acute VHS infection is characterised by a rapid onset and heavy mortality. Fish with acute VHS infection are lethargic, 
darker in colour, may have exophthalmia in one or both eyes and are anaemic. Haemorrhages are evident in the skin, eyes, and at the bases of the fins. Internally, punctiform haemorrhages are evident in periocular tissues, skeletal musculature of the abdominal wall and viscera; the liver appears mottled and hypoaemic while the kidneys are intensely red. In a latent infection, mortality is low and the fish could appear almost normal; however, they might be hyperactive. Virus concentration is found to be highest in the anterior kidney and the spleen, lesser in the liver and lowest in the heart and musculature. The virus spreads horizontally and survivors can be lifelong carriers. The isolation of VHSV in cell culture is the standard diagnostic method. Viral antigen can be detected in the inoculated cell cultures by indirect fluorescent antibody or immunoperoxidase staining (Meier \& Jorgensen 1975). Genetic analyses suggest that VHSV strains are closely related to other isolates from the same geographic region, rather than being grouped by host species. Phylogenetic analyses have identified 4 major genotypes of VHSV, designated I to IV. Genotype I contains a wide range of virus isolates; from freshwater rainbow trout farms in continental Europe that belong to Subgroup I-a (Snow et al. 1999, Einer-Jensen et al. 2004) and isolates from northern Europe of marine origin, which belong to Subgroup I-b within Genotype I. Genotype II consists of marine isolates from the Baltic Sea. Genotype III contains viruses from the North Sea (Einer-Jensen et al. 2004). The North American isolates belong to Genotype IV. VHS is classified as a notifiable disease by the World Organization of Animal Health (OIE) and listed as a non-exotic disease in the Council Directive 2006/88/EC of the European Commission (EC 2006).

In Slovenia, fish farming has a long tradition as the first brown trout eggs were already hatched in 1881 (Svetina 1982). Most of the Slovenian land is located in the alpine and pre-alpine region with numerous alpine rivers and streams, which enable trout farming. Trouts are produced for restoration purposes and for human consumption. For restoration, brown trout Salmo trutta m. fario, marble trout Salmo marmoratus Cuvier, lake trout Salmo trutta m. lacustris, brook trout Salvelinus fontinalis, huchen Hucho hucho and grayling Thymallus thymallus are produced, while for consumption the main production concentrates on rainbow trout. Until 1991, Slovenia was part of former Yugoslavia and all viral examinations were carried out at the Institute for Biology and Pathology of Fish and Honeybees of the Veterinary Faculty Zagreb, where, in the 1980s, the Rhabdovirus carpio virus and epithelioma papulosum cyprini (EPC) cells were established for the first time (Fijan et al. 1971, 1983). Yugoslavia was free of VHS until winter 1977/78 when the disease was suddenly diagnosed in 1 and 2 yr old farmed rainbow trout in Rižana near Koper (now Slovenian), resulting in 12.3 to $28.8 \%$ mortality in the $1 \mathrm{yr}$ old, but only 3.7 to $7.7 \%$ mortality in the $2 \mathrm{yr}$ old, marketable fish. Water temperature ranged between 10 and $11^{\circ} \mathrm{C}$ at that time (Ocvirk 1981). All remaining fish on the farm were sacrificed, removed and harmlessly destroyed. The fish farm was dried and disinfected, and after restocking, fish were clinically monitored and sampled regularly until 1985 (pers. comm.). After the first VHS outbreak, a monitoring programme for VHS, infectious pancreatic necrosis (IPN) and spring viraemia of carp (SVC) was started in Slovenia, which was less difficult to implement with only few fish farms existing at that time compared to today. After 1991, when Slovenia became an independent country and changes in the political system allowed private property, the number of fish farms increased enormously. Before joining the EU in 2004, there was a list of notifiable diseases comprising VHS, IPN, SVC and later infectious haematopoietic necrosis (IHN). In 1991, the Laboratory for Viral Fish Diseases was established at the Veterinary Faculty, University of Ljubljana, and started carrying out viral diagnostics. For VHS, SVC and IPN, there has been passive, active and targeted surveillance since 1985. For targeted surveillance, which was ordered by the Annual Decree and paid by the Veterinary Administration of the Republic of Slovenia, all trout hatcheries are monitored each year for VHSV and later IHN virus (IHNV) by sampling the ovary and seminal fluid of spawners. All movements of live fish are accompanied by health certificates signed by an accredited veterinarian. In case of a first finding of a listed disease, eradication is obligatory. Probably such a veterinary policy enabled Slovenia to remain free of VHSV between 1977 and 2007, whereas IHNV has been endemic in Slovenia for a long time.

In Slovenia, for the first time since 1977, VHSV was isolated from 2 clinically affected rainbow trout farms in November 2007. Thereafter, the infection spread and by the end of 2009, VHSV was confirmed at 6 different locations in southern Slovenia. We studied the epidemiology of the virus spread by comparing nucleotide sequences of 9 VHSV isolates with sequences available in the GenBank database.

\section{MATERIALS AND METHODS}

Monitoring programme of VHS in Slovenia. As part of the Slovenian national surveillance programme, all salmonid hatcheries are monitored for the presence of IHN and VHS viruses. For this purpose, at least one sampling of the ovary and seminal fluid of spawners is carried out per year. According to Slovenian veterinary 
law, all clinical cases presumptive for VHS and IHN are also sampled for laboratory examination. Sampling for the surveillance programme and sampling for diagnostic purposes are carried out by the veterinarians of the National Veterinary Institute (NVI) of the Veterinary Faculty, University of Ljubljana, and are paid by the Veterinary Administration of the Republic of Slovenia.

VHSV isolation and identification. On suspected fish farms, we collected live and dead fish showing typical clinical signs of VHS. Fish were dissected and the kidney, spleen and brain tissue were taken for examination. At least 10 affected fish were collected from each suspected farm and organs of every 2 fish were pooled into one sample, resulting in 5 samples from each affected farm. In the laboratory, $1 \mathrm{~g}$ of each sample was homogenized in $9 \mathrm{ml}$ minimum medium RPMI 1640 (Gibco; Invitrogen) by use of Ultra Turrax Tube Drive (IKA) and centrifuged at $3000 \times g$ for $15 \mathrm{~min}$ at $4^{\circ} \mathrm{C}$. A volume of $1 \mathrm{ml}$ of the supernatant was aliquotted in a separate tube and used for RNA extraction and RT-PCR. After centrifugation, antibiotic/ antimycotic (Gibco; Invitrogen) was added to the supernatant (final concentration $100 \mu \mathrm{l} \mathrm{ml} \mathrm{m}^{-1}$ ), which was then incubated for at least $2 \mathrm{~h}$ at $4^{\circ} \mathrm{C}$. A volume of $50 \mu \mathrm{l}$ of each supernatant (dilution 1:10) was inoculated in duplicate wells on $50 \mu \mathrm{l}$ of a $1 \mathrm{~d}$ old cell-seeded cultures of EPC and fry fibroblasts (BF-2) on a 96-well tissue culture plate (TPP). Two-fold dilutions were made on the plate, resulting in 8 dilutions per sample, starting with $1: 20$ to a final dilution of $1: 2560$. The inoculated EPC and BF-2 cells were incubated at $15^{\circ} \mathrm{C}$ and inspected every day for $7 \mathrm{~d}$. If no cytopathic effect (CPE) was visible after $7 \mathrm{~d}$, another first and second passage was processed and incubated for $7 \mathrm{~d}$ before the test was terminated. If CPE occurred in any of the 5 pooled samples from the same farm, VHSV was verified by RT-PCR (see 'RT-PCR amplification and sequencing') and an indirect immunoperoxidase test. The inoculated cells were fixed with $80 \%$ acetone. To each well, $100 \mu \mathrm{l} 3 \% \mathrm{H}_{2} \mathrm{O}_{2}$ were added for $10 \mathrm{~min}$, rinsed and cells incubated with working dilution of monoclonal antibody anti-VHS (Bio-x) for $1 \mathrm{~h}$ at $37^{\circ} \mathrm{C}$, washed and anti-mouse horseradish-peroxidase conjugated antibodies (HRP, anti Mouse immunoglobulin, P260, Dako; dilution 1:100) were added. Tests were read under an optical microscope after adding $100 \mu \mathrm{l}$ AEC substrate (3-amino-9-ethylcarbazole, Sigma) to each well. Cells containing VHSV were brown coloured.

RNA extraction. A set of 9 VHSV isolates was selected in order to represent all detected outbreaks and different locations of outbreaks. The original sample suspensions were used for RT-PCR to avoid cross-contamination during the isolation step. For each of the 9 selected CPE positive samples, $250 \mu$ l of the sample su- pernatants (dilution 1:10) prepared for virus isolation were used for RNA extraction. RNA was extracted from isolates using a RNA extraction kit (Trizol LS, Invitrogen) according to the manufacturer's instructions. Total RNA was eluted in $100 \mu \mathrm{l}$ nuclease free water.

RT-PCR amplification and sequencing. A part of the VHSV genome was amplified by RT-PCR with a specific VHS-1F (5'-GGA ATG GAA CAC TTT TTT CTT GG-3') and VHS-1R (5'-TGT GAT CAT GGG TCC TGG TG-3') primer pair (Miller et al. 1998) using a one-step RT-PCR kit (SuperScript ${ }^{\mathrm{TM}}$ One-Step RT-PCR with Platinum ${ }^{\circledR}$ Taq, Invitrogen). The reaction was performed in a total volume of $50 \mu \mathrm{l}$ containing $4 \mu \mathrm{l}$ RNA template, $18 \mu \mathrm{l}$ nuclease free water, $25 \mu \mathrm{l} 2 \times$ PCR mix (containing $2.4 \mathrm{mM}$ of each dNTP in $0.4 \mathrm{mM} \mathrm{MgSO}_{4}$ ), 20 pmol of each primer and $1 \mu$ l SuperScript ${ }^{\mathrm{TM}}$ OneStep RT-PCR enzyme mix (Invitrogen). The following thermal profile for RT-PCR was applied: reverse transcription at $50^{\circ} \mathrm{C}$ for $30 \mathrm{~min}$, denaturation step at $94^{\circ} \mathrm{C}$ for $2 \mathrm{~min}, 40$ cycles comprising denaturation at $94^{\circ} \mathrm{C}$ for $15 \mathrm{~s}$, annealing at $54^{\circ} \mathrm{C}$ for $30 \mathrm{~s}$ and elongation at $72^{\circ} \mathrm{C}$ for $1 \mathrm{~min}$, and final extension at $72^{\circ} \mathrm{C}$ for $10 \mathrm{~min}$. The amplified products were analyzed by conducting a $2.0 \%$ agarose gel electrophoresis and visualized under UV after ethidium bromide stain. PCR products from 9 representative tissue samples (here referred to as SLO 1 to SLO 9, to match the virus isolates from these tissue samples, Table 1) were sequenced in both directions using ABI 310 Genetic Analyzer (Applied Biosystems) with ABI PRISM dye terminator sequencing chemistry, according to the manufacturer's instructions. The resulting sequences were assembled with DNASTAR program and compared to the sequences published in NCBI GenBank database, using BLAST program. To confirm the first outbreak, the sequencing of the complete $G$ gene (1524 nt) of one VHS isolate designated SLO 3 was conducted at the European Union Community Reference Laboratory for Fish Diseases (CRL) located at the National Veterinary Institute, Technical University of Denmark, using the primers described in Einer-Jensen et al. (2004). Based on single sequences of each sample, a multiple alignment of the sequences was constructed using Clustal W and its neighbourjoining method to analyse genetic relationships among sequences, and final phylogenetic trees were drawn with the Phylip program (Felsenstein 1989). GenBankdeposited nucleotide sequences of representative VHS strains from Genotypes I, II, III and IV were used for comparative purposes.

\section{RESULTS}

Within the Slovenian national VHS monitoring programme, 444 samples of brood stock were collected in 
Table 1. Features of the 9 VHSV-positive samples from Slovenian trout farms that were analyzed in this study. Only unique sequences were submitted to GenBank and hence have accession nos. nt: nucleotide(s), (-): not applicable

\begin{tabular}{|c|c|c|c|c|c|c|}
\hline $\begin{array}{l}\text { Date of sample } \\
\text { collection }\end{array}$ & $\begin{array}{c}\text { Outbreak } \\
\text { no. }\end{array}$ & $\begin{array}{l}\text { Fish farm location } \\
\text { in Slovenia }\end{array}$ & $\begin{array}{c}\text { Estimated } \\
\text { mortality (\%) }\end{array}$ & $\begin{array}{c}\text { Name of } \\
\text { VHSV isolate }\end{array}$ & $\begin{array}{l}\text { Sequence data } \\
\text { (present study) (nt) }\end{array}$ & $\begin{array}{c}\text { GenBank } \\
\text { accession no. }\end{array}$ \\
\hline 26 Nov 2007 & $1^{\mathrm{a}}$ & Brežice & 80 & SLO 1 & 600 & GQ153531 \\
\hline 26 Nov 2007 & $1^{\mathrm{a}}$ & Brežice & 80 & SLO 2 & 600 & - \\
\hline 29 Nov 2007 & $1^{\mathrm{a}}$ & Brežice & 80 & $\mathrm{SLO} 3^{\mathrm{c}}$ & 1524 & GQ292534 \\
\hline 04 Dec 2007 & 2 & Krško & 30 & SLO 4 & 600 & - \\
\hline 08 Apr 2008 & 3 & Ilirska Bistrica & 15 & SLO 5 & 600 & GQ153532 \\
\hline 02 Oct 2008 & 4 & Krka & 25 & SLO 6 & 600 & GQ153533 \\
\hline 12 Feb 2009 & $5^{\mathrm{b}}$ & Dvor & 60 & SLO 7 & 600 & GQ153534 \\
\hline 12 Feb 2009 & $5^{\mathrm{b}}$ & Podbočje & 70 & SLO 8 & 600 & - \\
\hline 26 Feb 2009 & 6 & Črnomelj & 60 & SLO 9 & 600 & - \\
\hline \multicolumn{7}{|c|}{$\begin{array}{l}\text { a Three different samples were obtained from the farm where the first outbreak was detected: the first isolate was obtained } \\
\text { from dead fish (SLO 1) and the second one was isolated from affected sacrificed fish (SLO 2). Slovenian VHS Outbreak } 1 \text { was } \\
\text { officially confirmed from additional samples collected on November 29, } 2007 \text { by veterinarians of the National Veterinary } \\
\text { Institute (isolate SLO 3) } \\
\text { bamples were collected at } 2 \text { locations (Dvor and Podbočje); both fish farms belonged to the same farmer } \\
{ }^{c} \text { Designated '1455/07' in GenBank database }\end{array}$} \\
\hline
\end{tabular}

2007 and 2008, which all tested VHSVnegative in EPC and BF-2 cell cultures. However, on 26 November 2007, the first clinical outbreak of VHS was suspected in a small pond with rainbow trout for consumption and was officially confirmed as the first outbreak of VHS in Slovenia since 1977 by virus isolation from samples collected on 29 November. The first clinical outbreak of VHS was reported by the local veterinarian from Brežice, southern Slovenia (Fig. 1), while all following clinical cases were reported by veterinarians of the NVI, responsible for fish disease management.

During this first presumptive VHS outbreak (Outbreak 1), 3 different samples were collected; the first isolate (SLO 1) was detected from samples of dead fish sent by the local veterinarian, the second one (SLO 2) was isolated from additional samples of affected live and sacrificed fish-taken at our demand by a NVI VHS specialist as required by the Slovenian VHS surveillance programme - and the third one (SLO 3) was isolated from the samples we took ourselves when we visited the affected fish farm to observe the clinical signs of VHS and other conditions there. The official date of the first outbreak of VHS in Slovenia, however, was 29 November 2007 (VHSV isolate SLO 3). As early as $48 \mathrm{~h}$ after incubation, a cytopathic effect of VHSV isolates on EPC and BF-2 cell cultures was observed for all 5

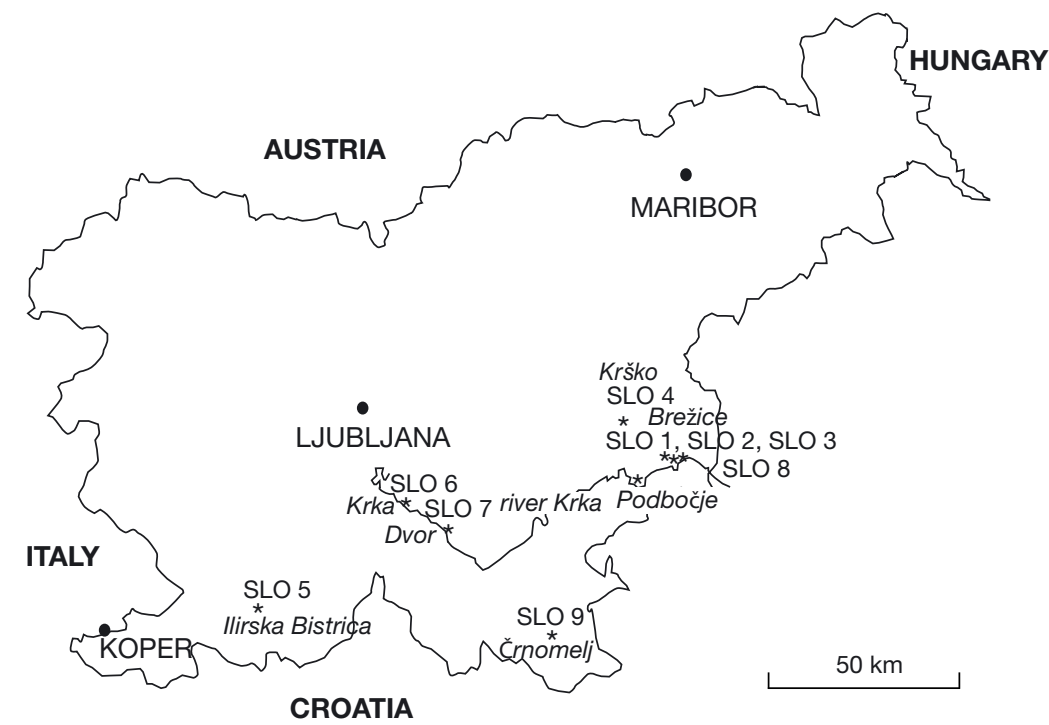

Fig. 1. Location of fish farms in Slovenia testing VHSV-positive between 2007 and mid-2009. Outbreaks (with associated VHSV isolate[s]) occurred as follows: Outbreaks 1 (isolates SLO 1 to SLO 3) and 2 (isolate SLO 4) in 2007; Outbreaks 3 (isolate SLO 5) and 4 (isolate SLO 6) in 2008; Outbreaks 5 (isolates SLO 7, SLO 8) and 6 (isolate SLO 9) in 2009

pooled samples from farms with confirmed VHS outbreaks. VHSV was confirmed by immunoperoxidase test with specific monoclonal antibodies. The propagation of isolates SLO 1, SLO 2 and SLO 3 was more intensive in BF-2 than in EPC. VHSV was also confirmed by specific RT-PCR. When the VHSV-positive diagnoses were confirmed, the veterinarians from the NVI visited all fish farms epidemiologically connected to the outbreaks. 
A week after the first outbreak, Outbreak 2 (with clinical signs of VHS) on a fish farm near Krško was confirmed by virus isolation (isolate SLO 4). In April 2008, Outbreak 3 (with clinical signs of VHS) in Ilirska Bistrica, southwest Slovenia, was confirmed (isolate SLO 5). In October 2008, Outbreak 4 was detected on a fish farm in Krka (isolate SLO 6). Downstream the same river Krka, in February 2009, Outbreak 5 with clinical signs of VHS infection and high mortality at 2 fish farms of the same owner in Dvor and Podbočje (isolates SLO 7 and SLO 8) was confirmed. The last VHS case (Outbreak 6) was confirmed 2 wk later in Črnomelj (isolate SLO 9), probably as a result of an import from a previously infected unit in Dvor (Table 1, Fig. 2). The virus isolates from the VHS outbreaks exhibited a cytopathic effect on EPC and BF-2 cell cultures that is typical of fish rhabdoviruses and were tested VHSV-positive by specific monoclonal antibodies of the immunoperoxidase test. After Outbreak 6 there were no further outbreaks in Slovenia until December 2009.

From the 9 selected VHSV-positive tissues, a specific RT-PCR product of $695 \mathrm{bp}$ was amplified with a specific primer pair. A partial nucleotide sequencing of the $G$ gene was performed on both strands for all 9 VHSV-positive tissue samples (SLO 1 to SLO 9) with primers used for PCR (VHS-1F, VHS-1R). The BLAST search, using the partial G-gene sequences (600 nt) from the present study, revealed a 99 to $100 \%$ identity with VHSV isolates from Europe confirming that the RT-PCR product was actually VHSV. For the 4 Slovenian sequences (600 nt), $100 \%$ identity was found among the isolates from Outbreaks 1 (SLO 1, SLO 2, SLO 3) and 2 (SLO 4) (Fig. 2, Table 2). The $600 \mathrm{nt}$ sequences from the following outbreaks, Outbreaks 3 to 6 (SLO 5 to SLO 9), were almost identical (99.8 to $100 \%$ ) to each other and the available sequences in GenBank isolated from Germany between 2006 and 2007 (VHSV isolates Dstg36-06, Dstg54-1-07, Dstg21-07). The 9 Slovenian VHSV isolates from the present study are genetically closely related and according to the epidemiological data and phylogenetic analysis, after the introduction of VHS to the country, the virus was transmitted via transportation of live fish from the farms of Outbreak 1 to the location where Outbreak 2 was confirmed, and from the location of Outbreak 5 to that of Outbreak 6, as $100 \%$ of nucleotide identity among the isolated virus strains was found. Genetic relationships of Slovenian isolates with some representative isolates of all known Genotypes I to IV (EinerJensen et al. 2004) revealed that all Slovenian VHSV strains are grouped within Genotype I-a together with European freshwater isolates (from Germany, Austria, Denmark, France and Switzerland) (Fig. 2, Table 2).

The complete nucleotide sequencing of the $G$ gene of isolate SLO 3 (named 1455/07 in GenBank) was done at the CRL in Denmark. A subsequent alignment
Table 2. GenBank accession numbers for VHSV isolates listed in Fig. 2

\begin{tabular}{|c|c|}
\hline VHSV isolate & GenBank accession no. \\
\hline \multicolumn{2}{|l|}{ Genotype I-a } \\
\hline Dstg54-1-07 & EU708809 \\
\hline Dstg21-07 & EU708804 \\
\hline Dstg36-06 & EU708807 \\
\hline SLO 1 & GQ153531 \\
\hline SLO 5 & GQ153532 \\
\hline SLO 6 & GQ153533 \\
\hline SLO 7 & GQ153534 \\
\hline SLO 3 (= 1455/07) & GQ292534 \\
\hline CH-FI262BFH & AY546571 \\
\hline AU-8/95 & AY546570 \\
\hline M2 & X59148 \\
\hline FR-0771 & AJ233396 \\
\hline FR-02-84 & U28800 \\
\hline DE-Fil3 & Y18263 \\
\hline DK-3946 & AY546586 \\
\hline DK-3971 & AY546587 \\
\hline DK-200098 & AY546605 \\
\hline DK-9695377 & AY546597 \\
\hline DK-9895174 & AY546603 \\
\hline DK-5740 & AY546590 \\
\hline FR-2375 & AY546617 \\
\hline \multicolumn{2}{|l|}{ Genotype I-c } \\
\hline DK-5131 & AF345858 \\
\hline DK-2835 & AY546585 \\
\hline DK-F1 & AF345857 \\
\hline \multicolumn{2}{|l|}{ Genotype I-d } \\
\hline FiA04.02 & AM086366 \\
\hline NO-A16368G & AY546621 \\
\hline \multicolumn{2}{|l|}{ Genotype I-b } \\
\hline DK-1p12 & AY546574 \\
\hline SE-SVA30 & AY546625 \\
\hline Cod Ulcus & Z93414 \\
\hline \multicolumn{2}{|l|}{ Genotype I-e } \\
\hline GE-1.2 & AY546619 \\
\hline \multicolumn{2}{|l|}{ Genotype III } \\
\hline DK-4p168 & AY546582 \\
\hline UK-MLA98/6 PT 11 & AY546632 \\
\hline \multicolumn{2}{|l|}{ Genotype II } \\
\hline DK-1p52 & AY546576 \\
\hline DK-1p53 & AY546577 \\
\hline \multicolumn{2}{|l|}{ Genotype IV } \\
\hline US-Makah & $\mathrm{U} 28747$ \\
\hline
\end{tabular}

of the complete $G$ gene of this isolate, including all available sequences from NCBI GenBank, revealed that Slovenian VHSV sequence from Outbreak 1 (SLO 3) was unique (GenBank accession no. GQ292534) (Fig. 3). The first source of VHS infection is unknown, but the complete G-gene sequence of SLO 3 revealed that this sequence is closely related to 3 German isolates with 99.0\% nucleotide identity (1510/1524 nt) and to isolate $\mathrm{CH}-\mathrm{F} 1262 \mathrm{BFH}$ with $98.8 \%$ nucleotide identity (1506/1524 nt). Trees with similar topology of 
all included isolates and subtypes were consistently produced when we used both 600 and 1524 nt of the $G$ gene (Figs. $2 \& 3$ ). These findings confirmed our hypothesis that short nucleotide sequences (600 and $1524 \mathrm{nt}$ ) can also successfully be used for reliable and fast genotyping of VHSV from outbreaks in the same region.

\section{DISCUSSION}

In November 2007, VHS was diagnosed in a rainbow trout fish farm in Slovenia for the first time since 1977 when the virus had been eradicated. The typical clinical and pathoanatomical signs were reported by a local veterinarian who examined fish from the put-and-take

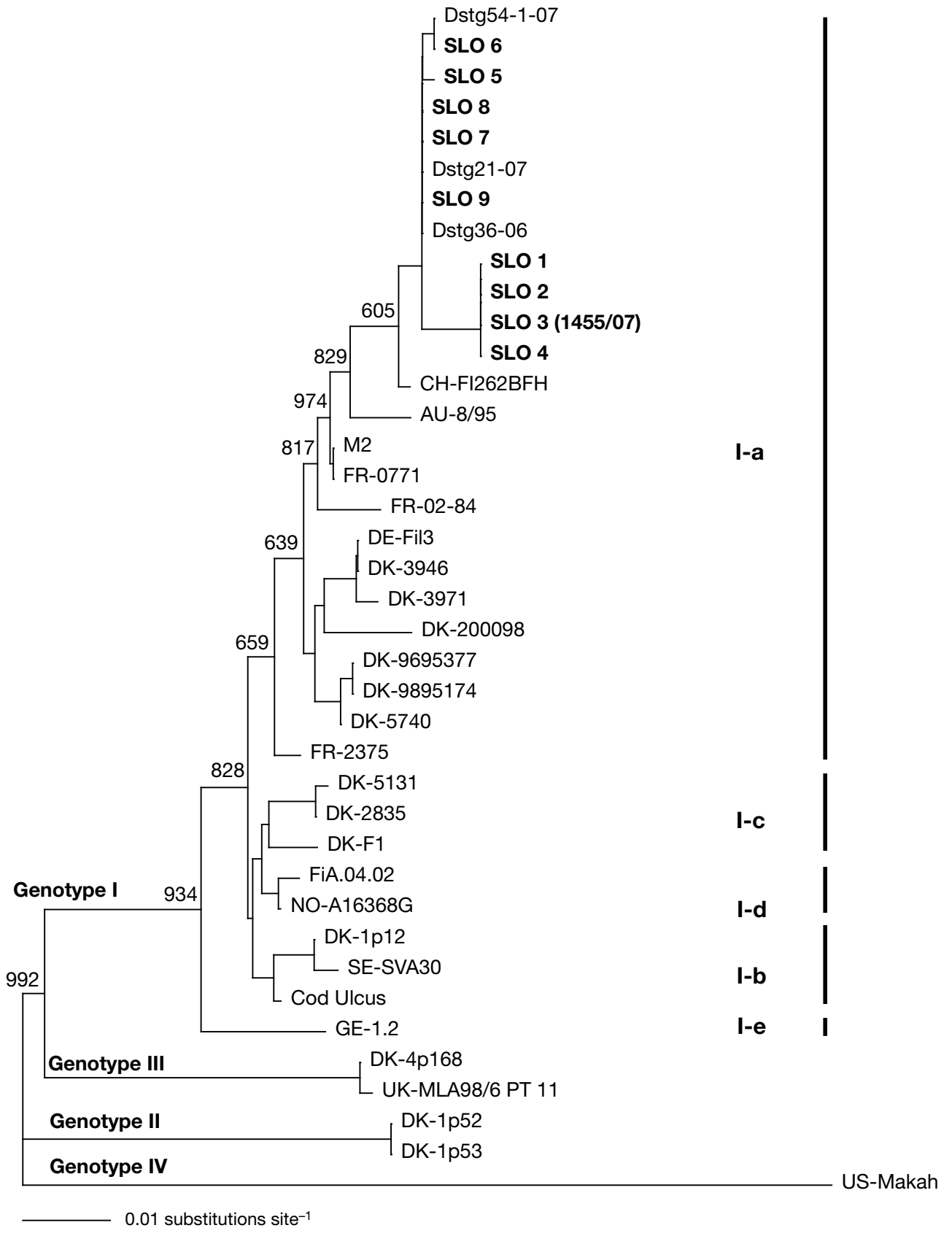

Fig. 2. Phylogenetic tree based on $600 \mathrm{nt}$ partial sequences of the VHSV $G$ gene (nucleotide positions 30 to 630 ), comparing Slovenian VHSV isolates (SLO 1, SLO 2, SLO 3 [= designation 1455/07 in GenBank], SLO 4 to SLO 9; shown in bold and originating in the present study) with representative isolates from VHSV Genotypes I-a, I-b, I-c, I-d, I-e, II, III, IV taken from the NCBI GenBank (see Table 2 for relevant accession numbers). The tree was computed by the neighbour-joining method using the PHYLIP Dnadist and Neighbour programs. Bootstrap values are given for 1000 replicate data sets, performed with PHYLIP Seqboot program (Felsenstein 1989) 
pond. The VHS outbreak was confirmed by virus isolation in EPC and BF-2 cell cultures, immunoperoxidase test and RT-PCR test. Between 2007 and 2009, VHSV was isolated from another 5 outbreaks (Table 1) and the molecular epidemiology of the collected isolates was studied. In total, 9 VHSV-positive samples were selected and a part of the G-gene sequence (600 nt) was determined. For one sample from the first outbreak (isolate SLO 3), the complete $G$ gene was sequenced. Based on the analysis of partial and complete $G$ gene, the Slovenian VHSV isolates were grouped together with the previously published isolates of Genotype I, Subgroup I-a. They were most closely related to recent German isolates with which they shared 99 to $100 \%$ nucleotide identity. Genotype I consists of isolates from continental Europe (Subgroup I-a), isolates from wild fish from the Baltic Sea (Subgroup I-b), isolates from farmed rainbow trout in Denmark (Subgroup I-c), isolates from Finland (Subgroup I-d) and isolates from the Black Sea area (Georgia and Turkey [Subgroup I-e]; Einer-Jensen et al. 2004 and Nishizawa et al. 2006, respectively). Although we used only $600 \mathrm{nt}$ of the $G$ gene for phylogenetic analysis in our study, the grouping of all selected viruses revealed 4 separate clades for Genotypes I to IV, and was consistent with results of the entire 1524 nt of the $G$ gene (Fig. 3) and with phylogenetic analyses performed by other authors (Einer-Jensen et al. 2004, 2005). A similar approach with partial sequencing of the $G$ gene was successful in genotyping VHSV isolates from the Turkish coastal area of the Black Sea (Nishizawa et al. 2006).

When studying the molecular epidemiology of Slovenian outbreaks at new locations, partial sequencing of the $G$ gene conducted in the present study proved to be a very convenient method for fast and reliable confirmation of the source of VHS infection. The phylogenetic study performed by Einer-Jensen et al. (2004, 2006) and Raja-Halli et al. (2006) demonstrated the presence of a continuous genetic evolution within Genotype I-a and I-d sub-lineages, which was also detected in the Slovenian outbreaks from 2007 onwards. According to the epidemiological investigation and phylogenetic analysis of the present study, it is highly probable, that there had been at least 2 independent introductions of VHSV-infected fish imported from very similar origins. Slovenian isolates from Outbreaks 1 and 2 (SLO 1 to SLO 4) share $100 \%$ nucleotide identity and support conclusions from the collected epidemiological data that Outbreak 2 was the result of trading between these 2 trout farms during the incubation period of Outbreak 1. Only 2 outbreaks were reported in 2008, Outbreak 3 in April and Outbreak 4 in October. The isolates from these 2 outbreaks (SLO 5 and SLO 6) shared $99.7 \%$ nucleotide identity, while sharing $99.0 \%$ nucleotide identity with samples of the first outbreak. The observed divergence level of $1 \%$, i.e. 6 nucleotide differences, is a quite high divergence for this short time period. According to this data, the possibility of a separate introduction of VHS from the same or a very similar source is very likely. The VHSV isolates detected in the last 2 outbreaks (5 and 6; SLO 7 to SLO 9) share $100 \%$ nucleotide identity but have $99.0 \%$ and $99.2 \%$ identities with samples from Outbreaks 3 and 1, respectively. The epidemiological data collected in the present study suggest that VHSV-positive fish were transported from the farm of Outbreak 5 during the incubation period to the fish farm where Outbreak 6 was confirmed. This probable cause of Outbreak 6 was confirmed by identifying $100 \%$ identical sequences among the VHSV viruses isolated (SLO 7, SLO 8 and SLO 9) from the affected fish of both outbreaks. The overall results of the present study, i.e. the varying degree of phylogenetic closeness among VHSV isolates and the results of the epidemiological investigations, suggest that some outbreaks at the different locations (Outbreaks 1 and 5) were the result of one or more introductions of VHSV to Slovenia from either a single reservoir, or very similar reservoirs, while other outbreaks clearly resulted from virus transmission among Slovenian farms (Outbreaks 1 and 2, 5 and 6). The first source of virus introduction to Slovenia remains unknown but our genetic analyses suggest that Slovenian VHSV strains are most closely related to other isolates from neighbouring countries of Slovenia and shows the highest identity (99.0 to $100 \%$ ) with isolates from Germany. This is supported by our epidemiological investigations of each individual VHS outbreak, which is the result of the free-trade policy in the EU. In Slovenia, there has been a national surveillance programme since the first outbreak of VHS in 1977; it has been running continuously except for a few years when Slovenia became independent and started to develop its own diagnostic for viral diseases. In the present study, we used only the monitoring data of the $2 \mathrm{yr}$ surveillance programme (2007 to 2008) and the samples of this monitoring period for the diagnostic purposes. All 444 samples collected from salmonid hatcheries monitored in 2007 to 2008 were VHSV-negative.

When Slovenia joined the EU in 2004, it took over all the relevant EU regulations which allow trading of fish between farms, and different countries, of the same health status. Because IHNV is endemic in Slovenia and fish farms are mainly of small production capacity, the farms are hardly competitive price-wise, and therefore, the import of eggs and fish for fattening is quite popular in Slovenia. The results of our molecular epidemiology study suggest that VHSV was introduced into the country via independent imports between 2007 and 2009, but from a very similar source; 
probably from one particular region. Before joining the EU, Slovenian legislation required a mandatory eradication of VHS, but the new legislation allows the production of the infected fish to continue, which constitutes the risk of the disease spreading naturally. Furthermore, illegal trade is also possible.
Although VHS was diagnosed in 7 fish farms it is still located mainly in the southeast of Slovenia. In order to keep the rest of the country free of the disease, VHS should still be considered as an exotic disease and an eradication programme should be started as soon as possible. It seems that this idea is becoming more

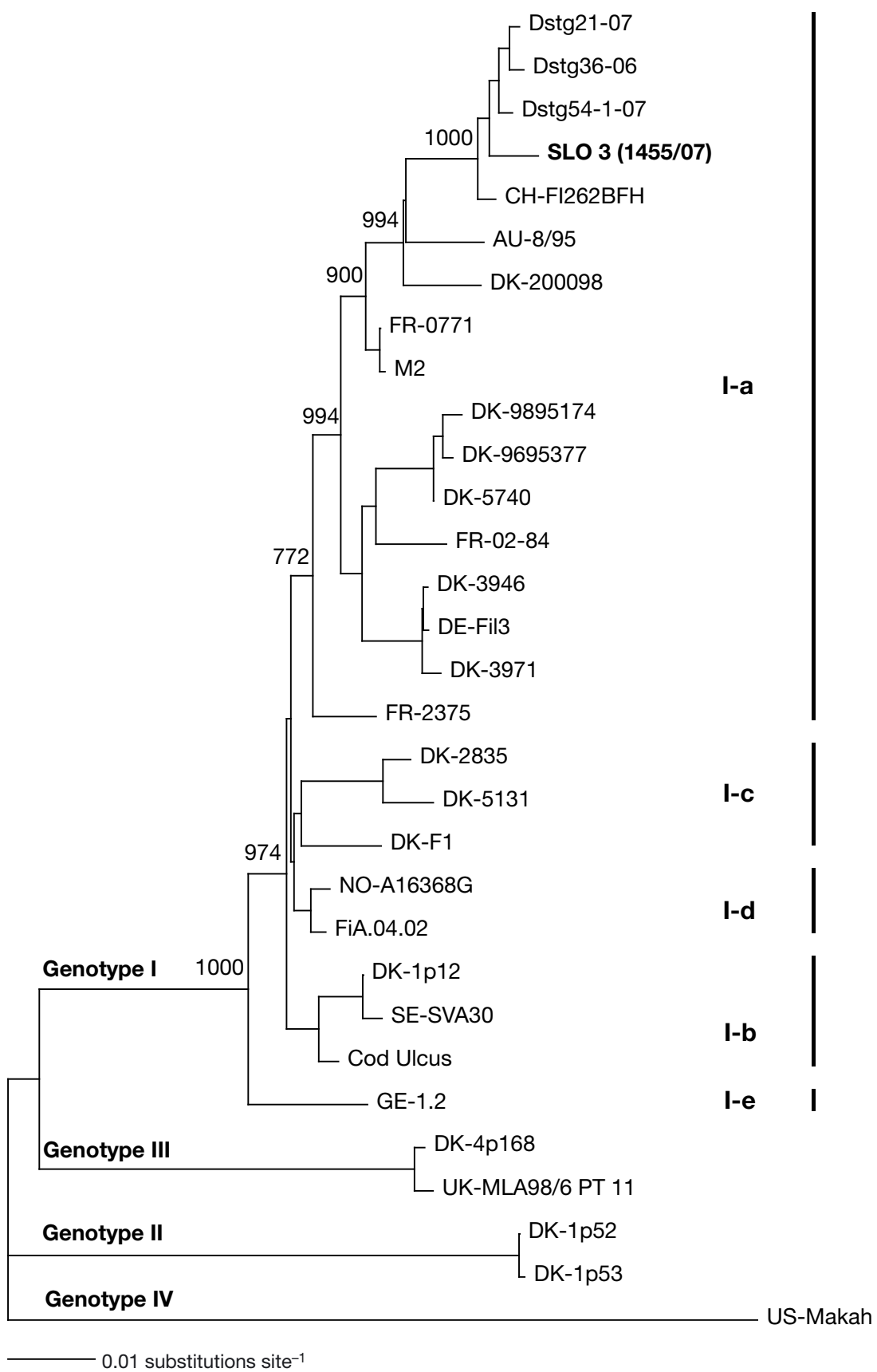

Fig. 3. Phylogenetic tree based on complete VHSV G-gene sequences (1524 nucleotides), comparing Slovenian VHSV isolate SLO 3 (= GenBank designation 1455/07 and accession no. GQ292534; in bold) from Outbreak 1 with representative isolates from VHSV Genotypes I-a, I-b, I-c, I-d, I-e II, III and IV (see Fig. 2, Table 2). The tree was computed by the neighbour-joining method using the PHYLIP Dnadist and Neighbour programs. Bootstrap values are given for 1000 replicate data sets, performed with PHYLIP Seqboot program (Felsenstein 1989) 
accepted. Previously, fish farmers thought that VHS was a disease similar to IHN, which had been present for a long time without heavy economic losses. However, in comparison to the IHN, VHS is a much more serious disease because large market-size fish are affected, with high mortality rates and subsequently causing high economic losses. We are encouraging fish farmers to start activities to establish a monitoring programme following the Council Directive 2006/88/EC with the goal of obtaining approved freedom from VHS. To conclude, it is necessary to emphasize that only this kind of fish health management is appropriate for Slovenian small-scale and fragmented aquaculture, which can only compete with European fish production by producing high-quality fish in a diseasefree country.

Acknowledgements. We thank the Veterinary Administration of the Republic of Slovenia for the financial support for sampling and laboratory testing. We also thank Aleksandra Grilc Fajfar, DVM for skilled technical assistance.

\section{LITERATURE CITED}

Dixon PF (1999) VHSV came from the marine environment: clues from the literature, or just red herrings? Bull Eur Assoc Fish Pathol 19:60-65

Einer-Jensen K, Ahrens P, Forsberg R, Lorenzen N (2004) Evolution of the fish rhabdovirus viral haemorrhagic septicaemia virus. J Gen Virol 85:1167-1179

Einer-Jensen K, Winton J, Lorenzen N (2005) Genotyping of the fish rhabdovirus, viral haemorrhagic septicaemia virus, by restriction fragment length polymorphism. Vet Microbiol 106:167-178

Einer-Jensen K, Ahrens P, Lorenzen N (2006) Genetic stability of the VHSV consensus sequence of G-gene in diagnostic samples from acute outbreak. Bull Eur Assoc Fish Pathol 26:62-67

EC (European Commission) (2006) Council Directive 2006/ 88/EC of 24 October 2006 on animal health requirements for aquaculture animals and products thereof, and on the prevention and control of certain diseases in aquatic animals. Off J Eur Union L 328:14-56

Felsenstein J (1989) Phylip phylogeny inference package (version 3.5c). Cladistics 5:164-166

Fijan N, Petrinec Z, Sulimanovic D, Zwillenberg LO (1971) Isolation of the causative agent from the acute form on infectious dropsy of carp. Veterinarski Arhiv 41: 125-138

Fijan N, Sulimanovic D, Bearzotti M, Muzinic D and others (1983) Some properties of the Epithelioma papulosum

Editorial responsibility: Julie Bebak,

Auburn, Alabama, USA cypriny (EPC) cell line from carp (Cyprinus carpio). Ann Inst Pasteur Virol 134:207-220

Jensen MH (1965) Research on the virus of Egtved disease. Ann N Y Acad Sci 126:422-426

Meier W, Jorgensen PEV (1975) A rapid and specific method for the diagnosis of viral hemorrhagic septicemia (VHS) in rainbow trout. Riv Ital Piscic Ittiopatol 10:1115

Miller TA, Rapp J, Wastlhuber U, Hoffmann RW, Enzmann PJ (1998) Rapid and sensitive reverse transcriptase-polymerase chain reaction based detection and detection and differential diagnosis of fish pathogenic rhabdoviruses in organ samples and cultured cells. Dis Aquat Org 34:13-20

Nishizawa T, Savas H, Isidan H, Üstündag C, Iwamoto $H$, Yoshimizu M (2006) Genotyping and pathogenicity of viral hemorrhagic septicemia virus from free-living turbot (Psetta maxima) in a Turkish coastal area of the Black Sea. Appl Environ Microbiol 72:2373-2378

Ocvirk J (1981) Virusna hemoragiãna septikemija pastrva: prikaz slučajeva bolesti I prve izolacije Egtved virusa u Jugoslaviji. Veterinarski fakultet Sveučilišta u Zagrebu Zavod za biologiju I patologiju riba I pãela. Magistrski rad. (Masters thesis)

OIE (World Organization of Animal Health) (2010) Viral haemorrhagic septicaemia. In: Manual of diagnostic tests for aquatic animals. OIE, Paris. Available at: www.oie.int/ eng/normes/fmanual/2.3.09.VHS.pdf

> Raja-Halli M, Vehmas TK, Rimaila-Pärnänen E, Sainmaa S, Skall HF, Olesen NJ, Tapiovaara H (2006) Viral haemorrhagic septicaemia (VHS) outbreaks in Finnish rainbow trout farms. Dis Aquat Org 72:201-211

Schütze H, Mundt E, Mettenleiter TC (1999) Complete genomic sequence of viral hemorrhagic septicemia virus, a fish rhabdovirus. Virus Genes 19:59-65

> Skall HF, Olesen NJ, Mellergaard S (2005) Viral haemorrhagic septicaemia virus in marine fish and its implications for fish farming - a review. J Fish Dis 28:509-529

Smail DA (1999) Viral hemorrhagic septicaemia. In: Woo PTW, Bruno DW (eds) Fish diseases and disorders, Vol 3: viral, bacterial and fungal infections. CAB International, Wallingford, p 123-147

Snow M, Cunningham CO, Melvin WT, Kurath G (1999) Analysis of the nucleoprotein gene identifies distinct lineages of viral haemorrhagic septicaemia virus within the European marine environment. Virus Res 63:35-44

Svetina M (ed) (1982) SladkovodNo. ribištvo na Slovenskem. RZS, Ljubljana

USGS (US Geological Survey) (2008) Molecular epidemiology of viral hemorrhagic septicemia virus in the Great Lakes region. US Department of the Interior, US Geological Survey, USGS FS 2008-3003. Available at: http:// wfrc.usgs.gov/pubs/factsheetpdf/vhsfs2011108.pdf

Wolf K (1988) Viral hemorrhagic septicaemia. In: Wolf K (ed) Fish viruses and fish viral diseases. Cornell University Press, Ithaca, NY, p 217-249

Submitted: January 12, 2010; Accepted: June 9, 2010

Proofs received from author(s): September 29, 2010 